\title{
Supporting Self-Determined Indigenous Innovations: Rethinking the Digital Divide in Canada
}

\author{
Jasmin Winter and Justine Boudreau
}

\author{
"To govern ourselves means to govern our stories and") \\ our ways of telling stories. It means that the rhythm of \\ the drumbeat, the language of smoke signals and our \\ moccasin telegraph can be transformed to the airwaves \\ and modems of our times. We can determine our use of \\ the new technologies to support, strengthen and enrich \\ our cultural communities.
}

\author{
Ahasiw Maskegon-Iskwew \\ Cree/French Métis New Media Artist \\ In "Drumbeats to Drumbytes Origins" (1994)
}

\begin{abstract}
This article seeks to revisit dominant narratives of digital technological development in Indigenous communities in Canada. By prioritizing Indigenous voices and drawing from concepts of self-determination and sovereignty, this analysis reorients discourse surrounding the "digital divide" towards a strength-based approach that positions Indigenous peoples as innovators and creators, not just consumers, of digital technologies. This article begins with a discussion of how dominant media has used technology and technological imagery to misrepresent Indigenous cultures and perpetuate colonial biases, and emphasizes the importance of making space for Indigenous future imagery. Following this is a discussion of digital storytelling and virtual landscapes, showcasing a small sample of Indigenous initiatives online, in video game and app development, and in augmented and virtual reality. Finally, this article considers the potential of "makerspaces" as a framework for future action to bridge theory and practice.
\end{abstract}

\section{Introduction}

The romanticized tale of Indigenous peoples' first interactions with cameras is all too familiar a narrative to the Western consciousness, portraying Indigenous peoples as fearful of the technology's ability to "steal souls" (Golub, 2004). Retrospectively, it is important to critically analyze what it truly was that 19th century photographers were "capturing" with their cameras, and how dominant media has used technology and technological imagery to hijack Indigenous realities and control the way that society views Indigenous peoples and cultures. Photography like that of Edward S. Curtis is often used as a reference point for this argument, as his pictures sought to explicitly erase any signs of modernity and reduce Indigenous lives to a simplistic, one-dimensional commodity that could be easily consumed by the colonial gaze. In his portraits, only expressionless faces and stoic poses were allowed, and traditional dress was mandatory - whether or not it came from the subject's own nation or the one over. In an infamous photograph titled "In a Piegan Lodge" (1910), Curtis' original image showed a clock (Figure 1), which he removed before publishing the edited version (Figure 2) (Stanford University, 2016).

Curtis bought into the colonial idea that it was the turn of the century and Indigenous peoples were disappearing (if not physically, then certainly culturally) and through his camera's lens, he thought himself able to salvage their legacy (Vizenor, 2000). In the words of Tsimshian-Haida writer Marcia Crosby (2002), this "salvage paradigm" dictates that those doing the saving choose what fragments of a culture they will salvage. In this case, Curtis was only salvaging his own perceptions, limiting control of Indigenous peoples over their own histories, their futures, and their relationship with technology. Curtis' photographs attempted to capture a 


\section{Supporting Self-Determined Indigenous Innovations: Rethinking the Digital Divide in Canada Jasmin Winter and Justine Boudreau}

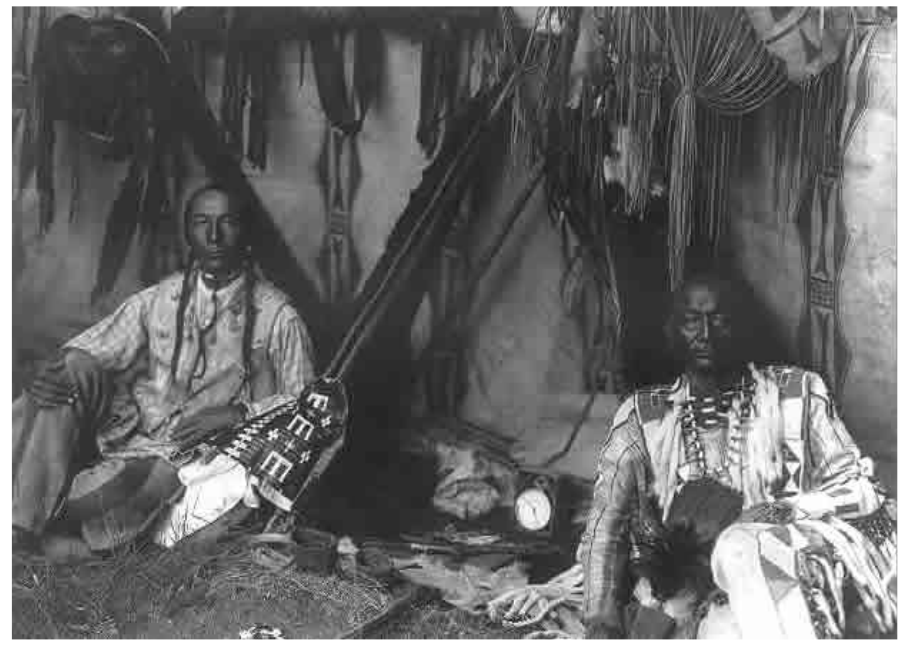

Figure 1. Original version of "In a Piegan Lodge"

(Edward S. Curtis, photographer, ca. 1910. Library of Congress: loc.gov/item/2002722455/)

static and "timeless" traditional Indigenous culture that would never change, one that could ultimately be used as a self-congratulatory reference point against which Eurocentric society could measure its own progressive evolution.

\section{Indigenous Worldviews and Future Imagery}

Mi'kmaw educator Marie Battiste and international human rights lawyer and advocate James (Sákéj) Youngblood Henderson (2011) outline the consequences of Western impositions of linear development models. They expose how a central concept behind Eurocentrism is "diffusionism", which is based on two assumptions: i) most human communities are uninventive, and ii) a few human communities (or places, or cultures) are inventive and are thus the permanent centres of cultural change or "progress". As Battiste and Henderson (2011) put it, "Diffusionism explains any progress made by non-Europeans as resulting from the spread of European ideas, which flow into the non-European world like air flows into a vacuum."

Julie Nagam (2016), a Professor of the History of Indigenous Art in North America, breaks down the binary associations of "civilized" and "savage" with technologically advanced and technologically unsophisticated, respectively. She emphasizes how Indigenous cultural knowledge is not static but in a constant state of flux, and is part of "a living and embodied practice", or in the words of author and historian Cynthia Landrum (2012), a "balancing act" between tradition

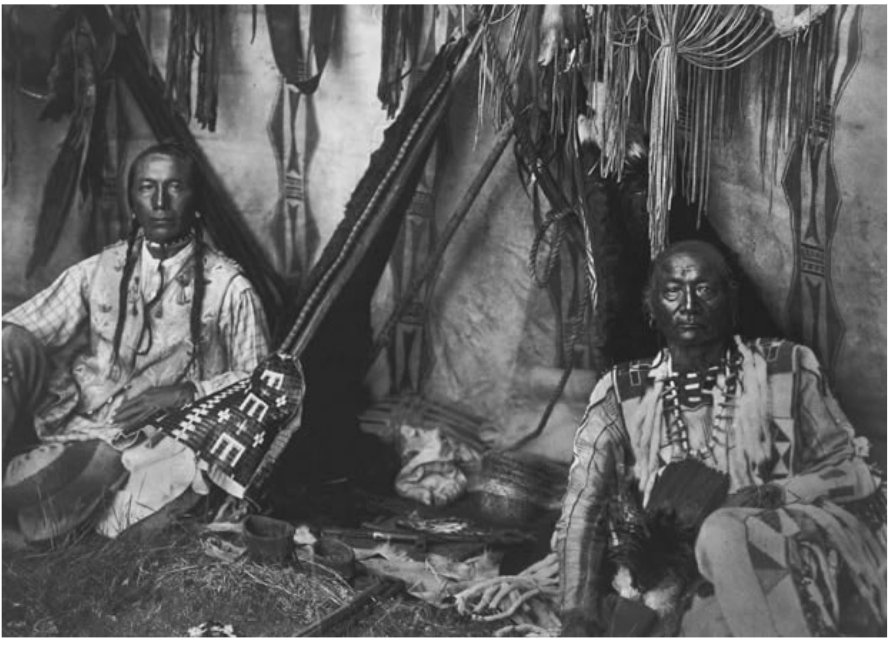

Figure 2. Published version of "In a Piegan Lodge", with the clock removed (Edward S. Curtis, photographer, 1911, in The North American Indian. scalar.usc.edu/works/performingarchive/in-a-piegan-lodge-l)

and modernity that does not dichotomize the past and present in a linear fashion. Nagam further contends that colonial impositions of timelessness and other "myths of modernity" have been thinly-veiled attempts at limiting the future for Indigenous peoples by presuming an inevitability in assimilation, echoing historic discourses that projected the disappearance of Indigenous peoples (Nagam, 2016). The work of Jason Lewis, a Professor and a Co-Founder of Aboriginal Territories in Cyberspace and the Initiative for Indigenous Futures, revolves around defying this suggestion. In a piece titled "A Brief (Media) History of the Indigenous Future," he states, "If you are not present in the future imaginary of the dominant culture - you're in trouble that means that they don't imagine you in the future... So we have to start proposing images of who we are and where we'll be" (Lewis, 2016). He goes on to outline five different ways to achieve this:

\section{Manifest the future with Indigenous peoples in it.}

2. Hybridize the present in new or extreme ways, modifying contemporary realities to open up future possibilities.

\section{Alter the past to lead to different futures.}

4. Shape digital infrastructure by engaging with digital media and digital culture.

5. Critique the past, and reflect on Indigenous creative engagements with technology. 


\section{Supporting Self-Determined Indigenous Innovations: Rethinking the Digital Divide in Canada Jasmin Winter and Justine Boudreau}

Lewis frames this plan of action using an Indigenous worldview of time and sustainability, which often calls for decisions to be made while thinking seven generations ahead and seven generations back. This circular way of thinking is just one example of how digital technological development may be approached differently when Indigenous peoples are able to assert their rights to digital self-determination and sovereignty, and there are countless more examples of how Indigenous innovators are already acting on Lewis' strategies.

\section{Rethinking the Digital Divide}

From a dominant international development perspective, documents such as the United Nations Declaration on the Rights of Indigenous Peoples (UN, 2008) lack any specific reference to technological development in their articulation of self-determination. This aspect has been better addressed at the meetings of the World Summit on the Information Society (WSIS; itu.int/net/wsis/), which were held in two phases in 2003 and 2005. During the first phase, more than 11,000 people from over 175 nations assembled in Geneva to discuss bridging technological divides. The WSIS has noted officially in their WSIS+10 Review Event:

"Indigenous and traditional knowledge are fundamental in building pathways to develop innovative processes and strategies for locally-appropriate sustainable development. This knowledge is integral to a cultural complex that also encompasses language, systems of classification, resource use practices, social interactions, ritual and spirituality. These unique ways of knowing are important facets of the world's cultural diversity, and provide a foundation for comprehensive knowledge society." (UNESCO, 2013)

Still, we argue that international literature continues to focus far too heavily on what technology can do for Indigenous peoples - not what Indigenous peoples have and can do with technology. To disrupt this pattern is to first and foremost re-focus discourse surrounding the digital divide from a needs-based approach to a strength-based approach, and subsequently prioritize support for bottom-up community initiatives.

According to interdisciplinary artist Cheryl L'Hirondelle: "A 'divide' evokes many different concepts and images. It is at once the opposite or taking away of multiplication, and it is the colonial tactic of gaining and maintaining power also known as a

\begin{abstract}
strategy of 'divide and conquer.' However, to many Native people a 'divide' also refers to the beautiful vistas and intricate landscapes of the geological term that connotes watersheds, ridges of land between two drainage basins, and/or that of the grandiosity of a continental divide." (L'Hirondelle, 2016)
\end{abstract}

L'Hirondelle makes a call to acknowledge Indigenous "pre-contact ingenuity as inventors and technologists experts in new media and avatars of innovation" (L'Hirondelle, 2016), with the aim of reformulating the very definition of technology. Her essay is an homage to the many "codetalkers, pathfinders, and cultural compilers" who came before her; those that have translated tradition and worldviews to ensure their accessibility as survival tools for future generations, much like a computer program that transforms source code into executable programs. She cites mnemonic devices such as the Plains tradition of pictorial calendars on tipis and skins, quillwork, weaving, beadwork, and Haudenosaunee wampum belts, among others, as examples of how data collection and documentary technologies have always been an integral part of Indigenous community-building.

Western impositions of dichotomous and binary thinking continue to place Indigenous peoples at the crossroads of false paradoxes that have limited their freedoms and placed Indigenous knowledge at the bottom of an imagined hierarchy. By recognizing and validating Indigenous epistemologies, or ways of knowing, we can better unpack the biases in Western thinking that have informed technological development practices and that have perpetuated economic, social, and cultural inequity. Within many Indigenous traditions of oral storytelling are lessons that directly address how to better engage with the multiplicity of life, often calling upon the Trickster (sometimes known as the Coyote): a dual character whose subversive behaviour helps the listener tease apart paradoxes. Steven Loft, editor of Coded Territories, likens digital technologies to the Trickster in the following terms: "Technology exists as shape shifter (not unlike the Trickster himself) neither inherently benign nor malevolent, but always acting and active, changing, transformative, giving effect to and affecting the world" (Loft, 2005). Digital technologies, therefore, hold incredible potential as tools to revitalize Indigenous stories in which are embedded Indigenous worldviews and ways of knowing that have strengthened communities since time immemorial. 


\section{Supporting Self-Determined Indigenous Innovations: Rethinking the Digital Divide in Canada Jasmin Winter and Justine Boudreau}

\section{Digital Storytelling}

In the words of prolific Coast Salish storyteller Lee Maracle: "Stories are the key to the endless oratory, the teachings, and the knowledge of our people. It's not all we are, but when we remember the story, the flood of knowledge locked behind it is let loose." (Maracle, 2015). Aman Sium and Erin Ritskes from the Ontario Institute for Studies in Education insist that stories become mediums for Indigenous peoples to both analogize colonial violence and resist it in real ways. They challenge liberal notions of stories as depoliticized acts of sharing or multicultural "show and tell," instead recognizing stories as acts of creative rebellion (Sium \& Ritskes, 2013). Judy Iseke, Canada Research Chair in Indigenous Knowledge and Research, also emphasizes the vital institution of eldership in traditional storytelling practices. Through the transgenerational memory transmitted by their stories, elders ensure the survival and continuance of Indigenous philosophies, theories, and epistemic traditions (Iseke \& Moore, 2011). Storytelling is in itself a tool for negotiating social priorities and contemporary community needs. Indigenous digital storytelling, therefore, can be used as a tool for Indigenous youth to learn about their identity, challenge negative representations of their culture, connect with others, and become agents of social change.

Jason Lewis and his partner, Mohawk multimedia artist Skawennati, summarize the impact that dominant technological media has had on Indigenous representation in the following terms:

"History has shown us that new media technologies can play a critical role in shaping how Western, technologically oriented cultures perceive Aboriginals. The camera, for instance, taught people that we all wore headdresses and lived in teepees. Cinema claimed that we spoke in broken English-if we spoke at all. [...] Traditional mass media such as newspapers, magazines, television, and film are expensive to produce and distribute and consequently exclude Aboriginal peoples. On the internet, we can publish for a fraction of the cost of doing so in the old media; we can instantly update what we publish in order to respond to misrepresentations, misunderstandings, and misreadings; and we can instantly propagate our message across a worldspanning network." (Lewis \& Fragnito, 2005)

Lewis and Skawennati have paved the way for Indigenous presence in digital spaces, beginning with the CyberPowWow project (cyberpowwow.net), which was launched in 1996. The site's main goals were to overcome stereotypes about Indigenous peoples, to help them shape the Internet, and to generate critical discourse about Indigenous art, technology, and community. These experiences built the foundation for Aboriginal Territories in Cyberspace, a research network based out of Concordia University in Montreal, Canada, and the Initiative for Indigenous Futures (abtec.org/iif/). In 2008, the Initiative for Indigenous Futures launched their Skins storytelling workshop, which have been applying these same principles through what author Naomi Alderman calls "the noise you're trying to get your children to turn down while you pen your thoughts about the future of location-based storytelling" (Alderman, 2015). Here, she is referring to video games, and Skins is founded on the practice of game modding, the term used to describe adapting or creating game content using commercial game engines. Through a mentorship model, participants take on game industry roles and are able to leverage the technical infrastructure of a game to create their own fully functional yet fully personalized game worlds based on community stories (Figure 3). Lameman and Lewis (2011) contend that video games, with their unique combination of story, design, code, architecture, art, animation, and sound, provide a rich medium that reflects traditions of oral storytelling and enables both developers and users to explore different strategies for pursuing cultural preservation and revitalization. Skins has had five iterations to date (all games are available online at: abtec.org/iif/workshops/past-workshops/), with the most recent workshop taking place in Honolulu, Hawai'i, at the request of Native Hawaiian community leaders. This has inspired other workshops such as Indigicade, the first installment of the collaboration between the Indigenous Routes Collective (indigenousroutes.ca) and Dames Making Games (dmg.to), which consisted of a month-long video game development session for Indigenous girls and women aged 13-24 in Toronto, Canada, during the summer of 2015 (Kestler-D'amours, 2015).

These workshops are giving rise to a new generation of Indigenous game designers who can provide alternatives to portrayals that have generally fallen into the Western game genre (with Indigenous characters as primitive enemies killed for reward) or science-fiction that perpetuates settler-colonial ideals of conquering seemingly uninhabited lands. They can also encourage the mobilization of companies such as Upper One Games (upperonegames.citci.org), the first Indigenousowned commercial gaming company in the United States, and the developers of the popular Never Alone

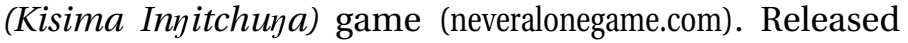




\section{Supporting Self-Determined Indigenous Innovations: Rethinking the Digital Divide in Canada Jasmin Winter and Justine Boudreau}
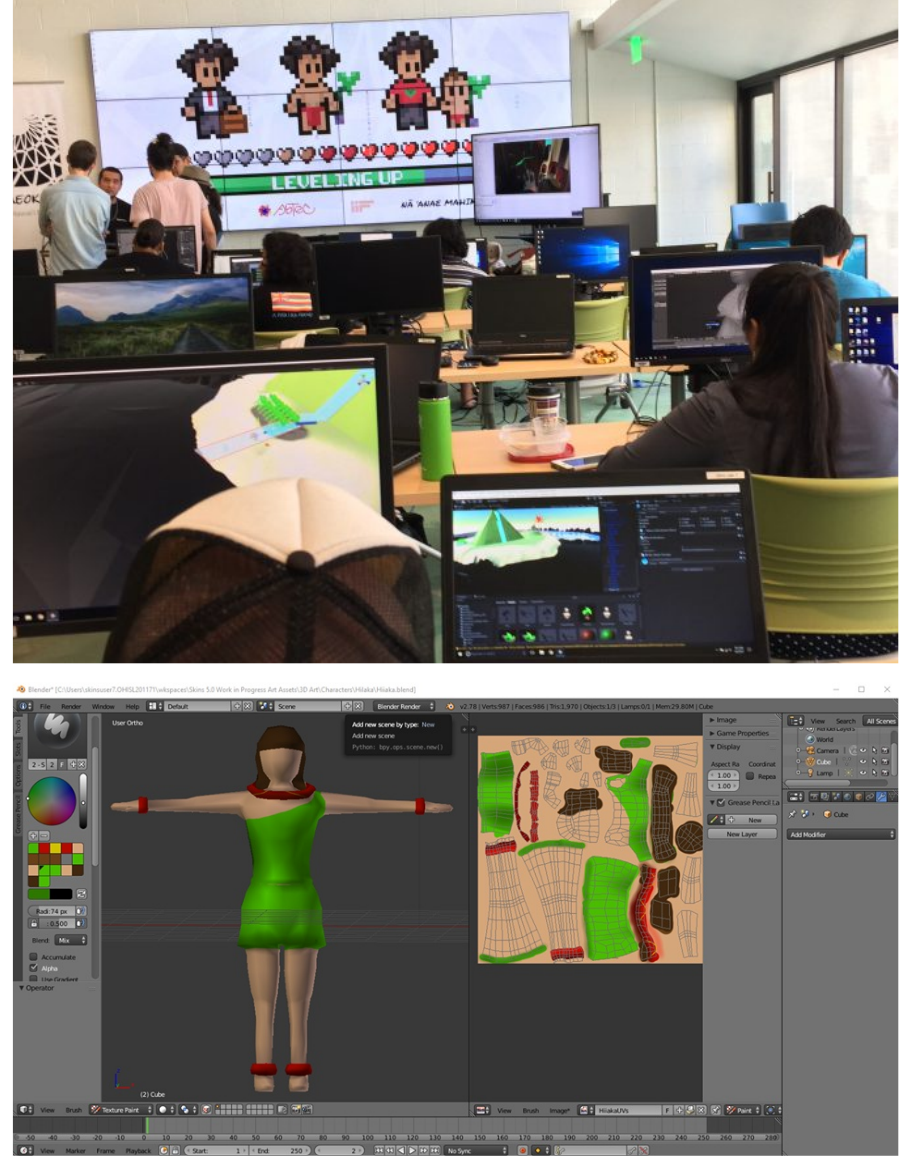

Figure 3. Photograph and screenshot from a Skins 5.0 workshop (Courtesy of Initiative for Indigenous Futures: skins.abtec.org/skins5.0/documentation/) in 2014, the puzzle-platformer adventure follows a young girl named Nuna and an arctic fox who set out to find the source of an external blizzard which threatens the survival of everything they have ever known (Figure 4). The game is based on the Iñupiaq tale, "Kunuuksaayuka", and is unique in the way that players can unlock live-action videos depicting Elders telling stories or showcasing different cultural practices and traditions that inspired the gameplay.

Envisioning Indigenous peoples at the forefront of video game development should come easily when one considers the longstanding tradition of telling stories that have helped communities virtualize their presence in the past, present, and future. However, when conceptualizations of the "real" world and the "virtual" world are dichotomized, Indigenous peoples find themselves once again stuck at another false paradox, one in which they face the need to challenge the trope of the "Ecological Indian" (Krech, 2000), a caricature of the complex relationship that Indigenous peoples have to place and the land.

\section{Virtual Landscapes}

Colonial assertions about the incompatibility of Indigenous ways of knowing and technology have been used to delegitimize claims to land in the past, manifesting in concepts such as "terra nullius", which is Latin for "nobody's land", explained in the following terms by author Alan Frost (1992):

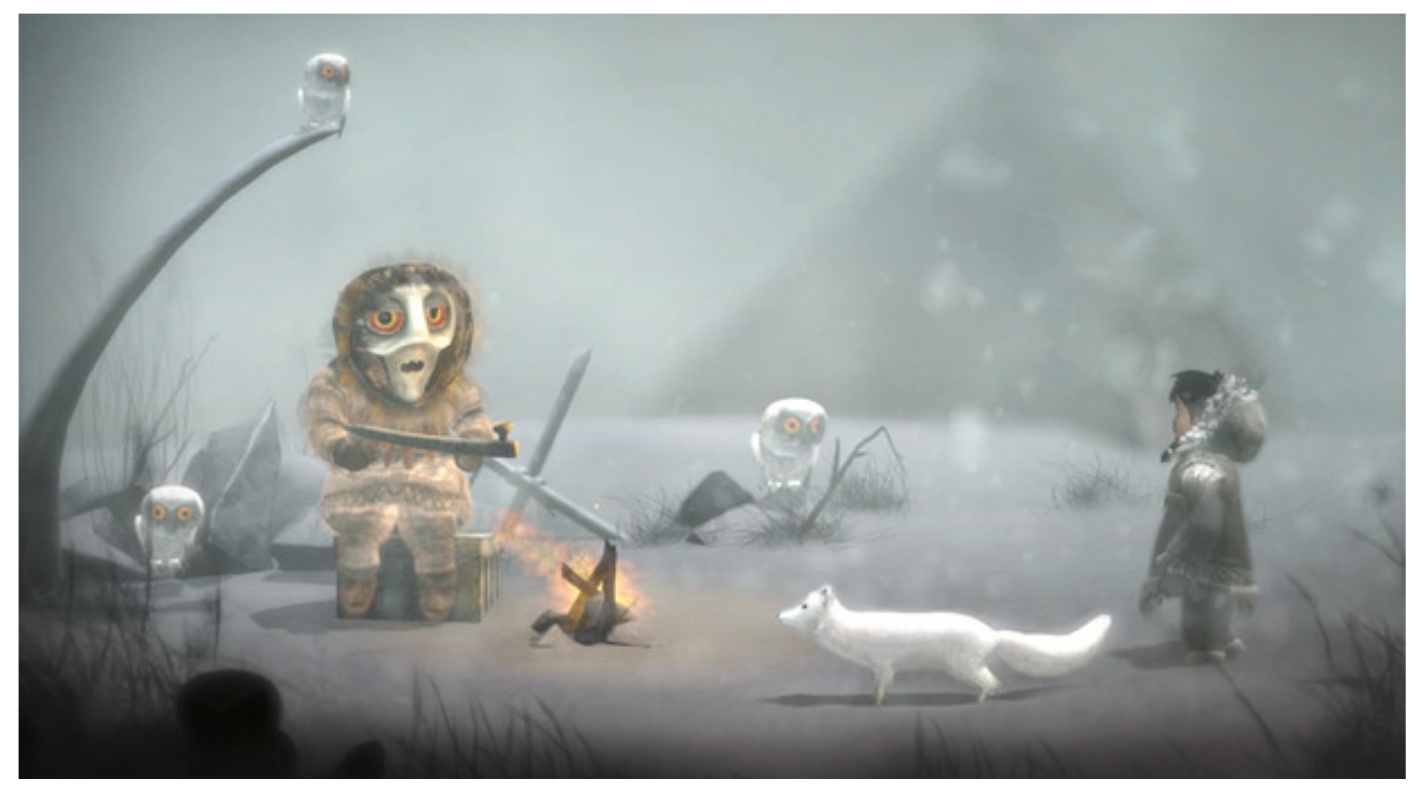

Figure 4. Screenshot of Never Alone (Screenshot courtesy of E-Line Media.) 


\section{Supporting Self-Determined Indigenous Innovations: Rethinking the Digital Divide in Canada Jasmin Winter and Justine Boudreau}

\begin{abstract}
"If Indigenous peoples had advanced beyond the state of nature only so far as to have developed language and the community of the family, but no further; if they had not yet mixed their labour with the earth in any permanent way; or if the region were literally uninhabited, then Europeans considered it to be terra nullius (i.e. belonging to no one), to which they might gain permanent title by first discovery and effective occupation."
\end{abstract}

This justification relies on a very specific interpretation of technological advancement, one that values labour and productiveness above language, community, and a balanced relationship with the environment. The idea that these things should be mutually exclusive is a fallacy, one that Indigenous innovators are challenging every single day. In "Terra Nullius, Terra Incognito," Jason Lewis (2005) turns the phrase on its head, suggesting that Indigenous people retain equal opportunities to gain place in virtual spaces. To quote Michelle Raheja, author of Reservation Reelism: Redfacing, Visual Sovereignty, and Representations of Native Americans in Film, digital space provides the land for "virtual reservations", which have the ability to transcend time and space, and it "initiates and maintains a dialectical relationship between the multiple layers of Indigenous knowledge systems - from the dream world to the topography of real or imagined landscapes" (Raheja, 2010).
Drawing once again from Cheryl L'Hirondelle:

"Connection to the land is what makes us Indigenous, and yet as we move forward into virtual domains we too are sneaking up and setting up camp - making this virtual and technologically mediated domain our own. However, we stake a claim here too as being an intrinsic part of this placethe very roots, or more appropriately routes. So let's use our collective Indigenous unconscious to remember our contributions and the physical beginnings that were pivotal in how this virtual reality was constructed." (L'Hirondelle, 2016)

This year, the Initiative for Indigenous Futures partnered with the Toronto International Film Festival (TIFF), imagineNATIVE Film and Media Arts Festival, and Pinnguaq, a Nunavut-based not-for-profit technology startup, to launch 2167 (imaginenative.org/2167/), a series that invited Indigenous innovators to create virtual reality projects set 150 years (seven generations) in the future. The works premiered in June 2017, including Blueberry Pie Under a Martian Sky by Scott Benesiinaabandan, which brings to life a prophetic Anishinaabe legend about a young boy who travels through a wormhole back to his people's place of origin and addresses concerns about the revitalization, growth, and evolution of the Anishinaabe language (TIFF, 2017).

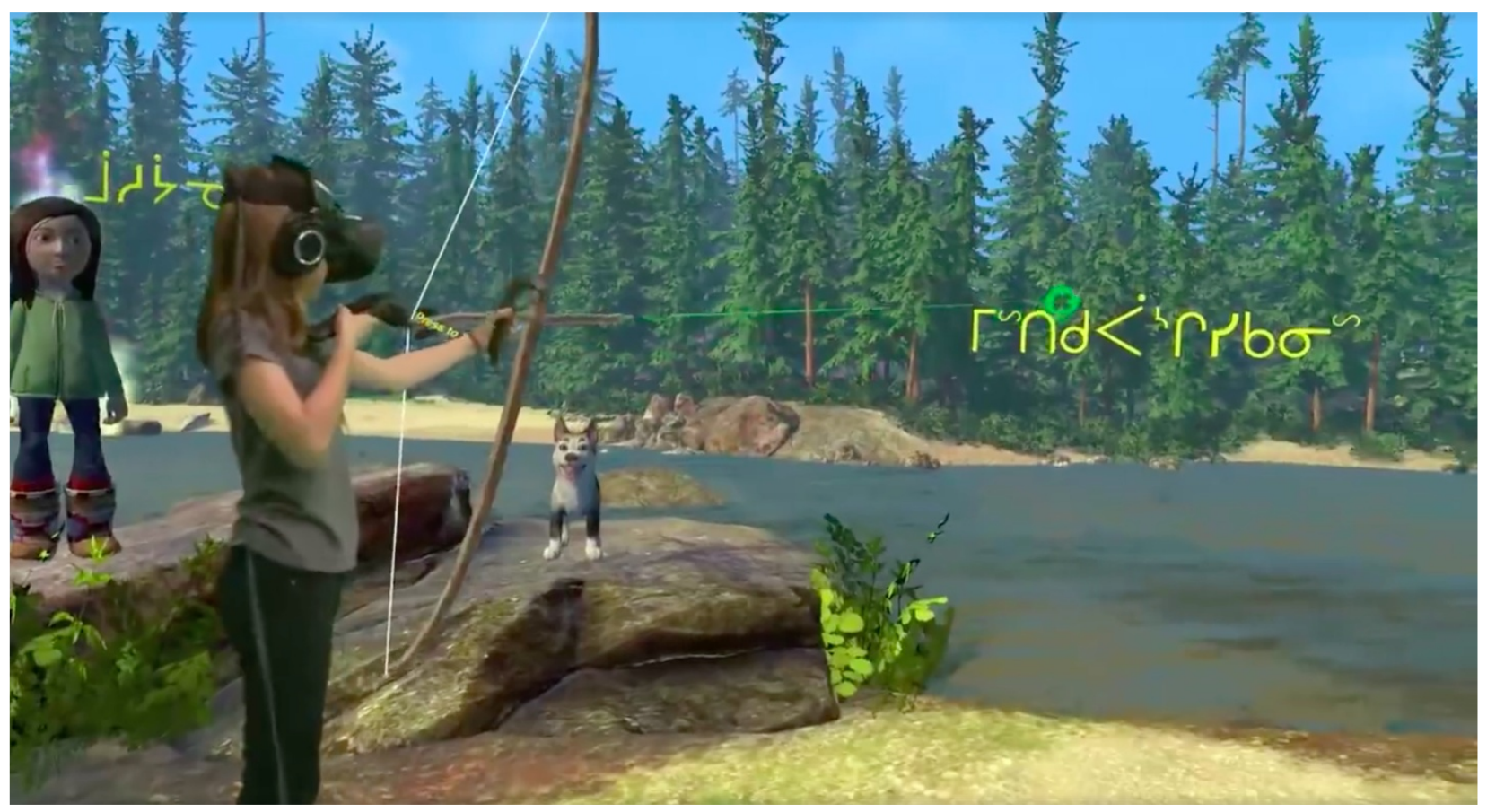

Figure 5. The Schoolū virtual camp (Screenshot courtesy of Katrina Metallic) 


\section{Supporting Self-Determined Indigenous Innovations: Rethinking the Digital Divide in Canada Jasmin Winter and Justine Boudreau}

As another example from Quebec, the company Minority Media has partnered with the James Bay Cree School Board to initiate a new virtual reality project called "Schoolū" (facebook.com/schooluvr/) that allows students to visit a virtual camp where they meet a little girl named Niipiish and her dog Achimush (Figure 5). While exploring the camp, Cree words that describe the seasons, the environment, and Cree traditions appear for the player to interact with as they wait for Niipiish's little brother's walking-out ceremony (Wapachee, 2016).

Adrian Duke, a technology entrepreneur from the Muscowpetung First Nation in Saskatchewan, is working on his own app called Wikiupedia (wikiupedia.com), which he describes as a "location-based story catching app that allows the Aboriginal community to share their stories, traditional knowledge, and any other information that they would like, using a bunch of different media sources" (Bambury, 2017). The app is named after a traditional Indigenous hut called a "wikiup". Like Wikipeida, users will be able to submit their own stories, which will be verified by cultural knowledge keepers. Like the infamous app Pokémon Go, users will have to go out and explore their local environment to unlock this knowledge (Bambury, 2017).

These examples are just some of many that help put the rest the notion that Indigenous peoples' local, context-specific place-based knowledge is somehow incompatible with digital technology. They also demonstrate how sovereignty in terms of land and territory is applicable to "visual sovereignty" or "screen sovereignty", which are descriptors for the importance of Indigenous control over their representations online, in video games, apps, and augmented and virtual reality development, and any medium that is helping information spread faster than ever before (Dowell, 2013). Indigenous innovators, using these new mediums to represent traditional knowledge, are demonstrating how Indigenous peoples have been navigating local and globalized contexts to connect with communities all over the world to advance their rights, balancing what unites Indigenous peoples internationally with what makes them unique and distinct. With all these examples in mind, it is easier to envision what Laurel Dyson (2004) of the University of Technology Sydney is saying when she argues that "Technology is only capable of furthering the agenda of the dominant culture if used to that end", reinforcing that Western hegemony need not be some invincible force.

\section{Makerspaces}

Finally, this article offers a practical pathway with which to address the digital divide, influenced by emerging "makerspaces", which are described by Roslund and Rogers (2013) as: "a general term for a place where people get together to make things. Makerspaces might focus on electronics, robotics, woodworking, sewing, laser cutting, programming, or some combination of those skills." The book entitled The Makerspace Playbook asserts that:

"Makerspaces come in all shapes and sizes, but they all serve as a gathering point for tools, projects, mentors, and expertise. A collection of tools does not define a makerspace. Rather, we define it by what it enables: tools." (EDUCAUSE, 2013)

Makerspaces are gaining traction in both entrepreneurial and community settings such as schools and libraries, and increasingly within rural settings through mobile makerspaces. A fundamental principle of makerspace culture is accessibility, and there is ample discussion of how to encourage inclusiveness and diversity, without having the terms become competing goals when one-size-fits-all approaches are applied.

The second author of this article, Justine Boudreau, is a Master's student in the Electronic Business Technologies program at the University of Ottawa, Canada, and has practical experience with makerspaces in Indigenous contexts. In March of 2016, a state of emergency was declared in Pimicikamak First Nation (Cross Lake, Manitoba) because of an increasing incidence of suicide, particularly among young people. Because of this,

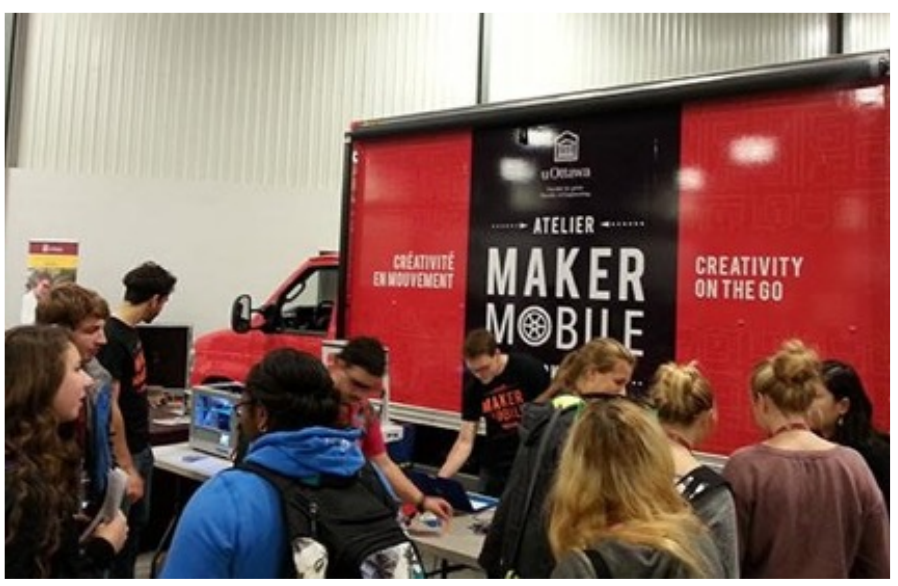

Figure 6. The uOttawa Maker Mobile (Photograph courtesy of Justine Boudreau) 


\section{Supporting Self-Determined Indigenous Innovations: Rethinking the Digital Divide in Canada Jasmin Winter and Justine Boudreau}

a local Indigenous artist reached out to the uOttawa Richard L'Abbé Makerspace (engineering.uottawa.ca/ makerspace) looking to see if they could provide some support. Through a partnership with Maker Mobile (engineering.uottawa.ca/makermobile), a sister organization that runs workshops in remote communities during the summer, and with funding from the University of Ottawa's Faculty of Engineering, a strategy to empower Cross Lake youth through community-driven making was set in motion. In advance of Boudreau and fellow student Danielle Taillon travelling to Winnipeg in early July, a 3D printer was bought and shipped to the University of Manitoba's Kidnetic program, with plans to bring and leave it in Cross Lake after teaching students and teachers how to use it. The curriculum details of the summer camp had to be modified upon Boudreau and Taillon's arrival as it was expected that there would be two age groups - up to about grade 7 and over grade 7 - but the participants ended up mostly being younger than grade 4 . The curriculum eventually included 3D modelling, 3D printing, coding, building structures on a budget, and making 3D printed jewelry. The days started slowly, with 10 to 15 students in the morning, and picked up after lunch with 20 to 30 students, a majority of which were girls. The activities usually lasted for around one and a half hours with breaks in between where everyone could spend some time outside. However, sometimes it was impossible to pull the kids away from their creations made using the Tinkercad (tinkercad.com) 3D modelling software, so the activity would continue throughout the afternoon. The activities were held in a computer lab where each participant had access to a computer, which made it easier to do $3 \mathrm{D}$ modelling and programming. There were not many adults around during the day, which made it harder to teach the kids how to use the 3D printer, but instructions were sent to the youth coordinator contact in the community. During that summer, three other communities near and on Manitoulin Island, Ontario, were visited in for week-long camps: Sheshegwaning First Nation, M'Chigeeng First Nation, and Whitefish River First Nation.

Unfortunately, because of the nature of these one-week summer camps, it is difficult to assess the outcomes of the project. The incredible creative and artisanal talents in the community can definitely make good use of a 3D printer. Children as well as adults have the capability to use this technology, and the hope is that it can provide a source of engagement and be a creative outlet for the community. If Maker Mobile would be able to return to any of the communities, the impact may be more tan- gible and the lasting effects of the visits would be more readily assessed. The hope is always to be able to go back and visit a community to be able to continue the learning as well as not leave an impression of abandonment. Unfortunately, because of the geographical distance, this is often not possible.

\section{Gathering STEAM}

As community spaces for innovation, makerspaces may serve as a point of discussion for how to encourage, for example, alternative pedagogies and educational practices to connect youth and elders to help promote intergenerational knowledge transmission. Drawing from innovations presented in this article, this could include building equipment for land-based education, hunting, and trapping, all the while encouraging language revitalization. Consider a recent example from 2017, when Boudreau joined the Marker Mobile team to introduce Indigenous youth at Gloucester High School in Ottawa, Canada, to principles of engineering and innovation through a program called InSTEM (actua.ca/en/ programs/national-aboriginal-outreach-program). At the Ontario Makers and Mentors Innovation Conference in November of that year, Paula Hall, Vice-Principal at Gloucester High School, presented some of the final projects created by these students, one of which included a prototype for a water filtration system for communities without access to clean drinking water (Hall, 2017).

Moreover, this article has purposefully emphasized how Indigenous innovations often lie at the intersection of art and technology, promoting a STEAM (science, technology, engineering, art, and math) model rather than just STEM. Wapikoni (wapikoni.ca), a project based in Quebec, while not officially labelling itself a makerspace, is the most far-reaching initiative to bring digital tools to northern Indigenous communities to date. The team has been conducting a travelling audiovisual studio that has trained and allowed Indigenous youth to see their stories come to life for screenings across Canada since 2004.

Earlier, we discussed Julie Nagam's assertion that Indigenous cultural knowledge is always evolving as part of "a living and embodied practice" (Nagam, 2016). Through her project titled "Transactive Memory Keepers (TMK): Indigenous Public Engagement in Digital and New Media Labs and Exhibitions", Nagam hopes to honour Indigenous innovations like the ones presented in this article, and draw inspiration from Wapikoni, by investigating the potential for building an open-source 


\section{Supporting Self-Determined Indigenous Innovations: Rethinking the Digital Divide in Canada Jasmin Winter and Justine Boudreau}

digital media mobile lab created by Indigenous peoples and for Indigenous communities. The TMK project, while still considering tools such as $3 \mathrm{D}$ printers and laser cutters, sees digital and new media tools as most relevant. The TMK project contends that "the principals of Indigenous methodologies are collaboration, learning by doing, and involving community members" (Nagam, 2015). In this sense, the project proposes that thinking about makerspaces in Indigenous communities should mean connecting contemporary Indigenous innovations to makerspace theories, and back to traditional Indigenous knowledge in a circular way that finds the common thread of community wellbeing. A fundamental research question that will be addressed is: If you bring a mobile lab into a community, and produce great results, how does the community benefit over the long term without ongoing access to the full equipment, and what happens to the project mentors or people involved? The answers to this, of course, will necessarily draw from Indigenous understandings of sustainability such as the seventh generation principle. Focusing an Indigenous makerspace on strengthening digital infrastructure and information and communication technologies has the added benefit of connecting communities to instructors and mentors even when they cannot physically be there.

Perhaps the most challenging aspect of the TMK project will be digging deep into the "open source" philosophy, which is characteristic of existing makerspace communities, as the makerspace model has its roots as a response to corporate patents and commercialization. For Indigenous communities, however, the flip side of all the potential that technology holds to revitalize Indigenous stories and worldviews is apprehension towards a Western form of liberalism that does not adequately address the appropriation of knowledge and culture. Coming full circle, it is this sound logic that has fostered apprehension towards technologies (such as the camera) yielded by European hands, not the technologies themselves. Technological development projects in Indigenous communities must explicitly acknowledge the logic of colonial institutions and legislation, which have attacked Indigenous knowledge transmission and data collection through isolating communities both geographically as well as socially, through the fracturing of familial ties and the punishment of language use and ceremonies. At the very least, these projects should promote intellectual property standards that reflect Indigenous ways of knowing. Ideally, future projects will take note of Indigenous-led initiatives like the ones presented in this article, and focus on facilitating Indigenous control over project designs to foster technological self-determination and sovereignty.

\section{Conclusion}

Rejecting needs-based, solution-oriented fixes to the socalled "digital divide" necessitates a process of challenging Eurocentric myths of modernity and recognizing how Indigenous peoples have always been innovators when it comes to tools of survival. Technological development in Indigenous communities demands a more thoughtful, and oftentimes more uncomfortable, approach to reconciliation that looks to the past in order to look to the future. This article has presented but a sample of the plethora of ways in which Indigenous peoples are making space in digital environments for their worldviews and ways of knowing, and projecting themselves into a future that dominant society would have them believe will not exist. Makerspaces, while brimming with potential as a pathway towards strengthbased technological development, can only truly do so if their project designs are informed by Indigenous worldviews and methodologies that draw on the strengths of Indigenous communities.

In conclusion, yes, visit websites created by Indigenous peoples. Use their apps, play their video games, and witness their presence in augmented and virtual reality, but do so critically, acknowledging that these virtual landscapes do not offer access to another lived experience. Listen closely, instead, to the lessons about our world, the "real", the "virtual", and everything in between, that are more relevant now than ever. Keeping the above in mind, this article serves primarily as an introduction to the topic, and there is much to explore when it comes to each initiative. 


\section{Supporting Self-Determined Indigenous Innovations: Rethinking the Digital \\ Divide in Canada Jasmin Winter and Justine Boudreau}

\section{About the Authors}

Jasmin Winter is a recent graduate of the Master's in Development Practice program at the University of Winnipeg, which stands on Treaty 1 territory. Originally from Vancouver, on the unceded lands of Coast Salish peoples, Jasmin was raised by a European father and a Chinese mother. This article contains material from a Major Research Paper that was graciously supervised by Dr. Julie Nagam. Jasmin completed a field placement with the Initiative for Indigenous Futures in the summer of 2017, and was a research assistant for the Transactive Memory Keepers project. She is currently working for the First Nations Technology Council in British Columbia. She is incredibly grateful to have had these opportunities to support Indigenous-determined innovations.

Justine Boudreau completed her undergraduate degree in Mechanical Engineering at the University of Ottawa, Canada, and is now working on a Master's degree in Electronic Business Technologies. During the last three years, she has spent her time playing with new technology and diversifying her knowledge. She spent almost two years working with the Maker Mobile delivering workshops and integrating new curriculum for robotics and women in science and engineering. She then moved on to work for the uOttawa Richard L'Abbé Makerspace while teaching and running the first and second year engineering design courses run through the Makerlab.

\section{References}

Alderman, N. 2015. The First Great Works of Digital Literature Are Already Being Written. The Guardian, October 13, 2015. Accessed February 15, 2018:

https://www.theguardian.com/technology/2015/oct/13/videogames-digital-storytelling-naomi-alderman

Bambury, B. 2017. Tech Entrepreneur Adrian Duke is Building an Augmented Reality App to Tell Indigenous Stories. CBCRadio Day 6, March 10, 2017.

http://www.cbc.ca/radio/day6/episode-328-cia-secrets-leakedphyllis-diller-s-gag-file-virtual-indigenous-history-and-more1.4015018/tech-entrepreneur-adrian-duke-is-building-anaugmented-reality-app-to-tell-indigenous-stories-1.4015037

Battiste, M., \& Henderson, J. (Sákéj) Y. 2011. Eurocentrism and the European Ethnographic Tradition. In M. C. Sunseri (Ed.), Racism, Colonialism, and Indigeneity in Canada: 11-19. Oxford: Oxford University Press.
Crosby, M. 2002. Construction of the Imaginary Indian. In J. Giltrow (Ed.), Academic Reading: Reading and Writing Across the Disciplines: 488-498. Peterborough, Canada: Broadview Press.

Dowell, K. 2013. Sovereign Screens: Aboriginal Media on the Canadian West Coast. Lincoln, NE: University of Nebraska Press.

Dyson, L. E. 2004. Cultural Issues in the Adoption of Information and Communication Technologies by Indigenous Australians. In F. Sudweeks \& C. Ess (Eds.), Proceedings of the Fourth International Conference on Cultural Attitudes towards Technology and Communication (CATaC): 58-71. Karlstad, Sweden, June 27-July 1, 2004.

Frost, A. 1992. Old Colonisations and Modern Discontents: Legacies and Concerns. In Proceedings of the Inaugural Conference of The Samuel Griffith Society: 116-126. Hilton-on-the-Park, Melbourne. http://www.samuelgriffith.org.au/papers/html/volume\%201/chap 11.htm

Golub, A. 2004. Copyright and Taboo. Anthropological Quarterly, 77(3): 521-530.

https://doi.org/10.1353/anq.2004.0039

Hall, P. 2017. InSTEM: Empowering Indigenous Youth through Social Change. Presented at the Ontario Makers and Mentors Innovation Conference, Ottawa, Canada.

Iseke, J., \& Moore, S. 2011. Community-based Indigenous Digital Storytelling with Elders and Youth. American Indian Culture and Research Journal, 35(4): 19-38. http://www.ourelderstories.com/wpcontent/uploads/pdf/CommunityBasedIndigenousDigitalStorytell ing_2011.pdf

Kestler-D'Amours, J. 2015. Creating Video Games Help Indigenous Girls Boost Self-Confidence. The Star, June 15, 2015. Accessed February 15, 2018:

https://www.thestar.com/news/gta/2015/06/15/creating-videogames-help-indigenous-girls-boost-self-confidence.html

Krech, S. 2000. The Ecological Indian: Myth and History. New York: W.W. Norton \& Company.

Lameman, B. A., \& Lewis, J. E. 2011. Skins: Designing Games with First Nations Youth. Journal of Game Design and Development Education, 1: 54-63.

Landrum, C. L. 2012. Kicking Bear, John Trudell, and Anthony Kiedis (of the Red Hot Chili Peppers): "Show Indians" and Pop-Cultural Colonialism. The American Indian Quarterly, 36(2): 182-214.

Lewis, J. E. 2005. Terra Nullius, Terra Incognito. Blackflash, 21(3): 16-19.

Lewis, J. E. 2016. A Brief (Media) History of the Indigenous Future. Public, 27(54): 36-50.

Lewis, J. E., \& Fragnito, S. T. 2005. Aboriginal Territories in Cyberspace. Cultural Survival, 29(2): 29-31. https://www.culturalsurvival.org/publications/cultural-survivalquarterly/aboriginal-territories-cyberspace

Loft, S. 2005. Aboriginal Media Art and the Postmodern Conundrum: A Coyote Perspective. In Townsend, M., Claxton, D. \& Loft, S. (Eds.), Transference, Tradition, Technology: Native New Media Exploring Visual \& Digital Culture: 88-103. Banff, Canada: Walter Phillips Gallery Editions 


\section{Supporting Self-Determined Indigenous Innovations: Rethinking the Digital \\ Divide in Canada Jasmin Winter and Justine Boudreau}

L'Hirondelle, C. 2016. Codetalkers Recounting Signals of Survival. In K. Swanson \& S. Loft (Eds.), Coded Territories: Tracing Indigenous Pathways in New Media Art: 147-168. Calgary: Calgary University Press.

Maracle, L. 2015. Memory Serves: Oratories. Edmonton, Canada: NeWest Press.

Maskegon-Iskwew, A. 1994. Drumbeats to Drumbytes Origins. Drumbytes.org: Aboriginal Media Art. Accessed February 17, 2018: http://drumbytes.org/about/origins-1994.php

Nagam, J. 2015. About the Project. Transactive Memory Keepers: Digital and New Media Mobile Laboratories. Accessed September 19, 2017:

http://www.transactivememorykeepers.org

Nagam, J. 2016. Deciphering the Refusal of the Digital and Binary Codes of Sovereignty/Self-Determination and Civilized/Savage. Public, 27(54): 78-89.

https://doi.org/10.1386/public.27.54.78_1

Raheja, M. H. 2010. Reservation Reelism: Redfacing, Visual Sovereignty, and Representations of Native Americans in Film. Lincoln, NE: University of Nebraska Press.

Roslund, S., \& Rodgers, E. 2013. Makerspaces: 21st Century Skills Innovation Library: Makers as Innovators. North Mankato, NM: Cherry Lake Publishing.

Sium, A., \& Ritskes, E. 2013. Speaking Truth to Power: Indigenous Storytelling as an Act of Living Resistance. Decolonization: Indigeneity, Education \& Society, 2(1): I-X. http://www.decolonization.org/index.php/des/article/view/19626 $/ 16256$

TIFF. 2017. 2167: Indigenous Filmmakers and Artists Imagine Indigenous Life 150 Years in the Future in New VR projects. Toronto International Film Festival (TIFF). Accessed February 15, 2018:

http://www.tiff.net/events/2167/

UN. 2008. United Nations Declaration on the Rights of Indigenous Peoples. New York: United Nations (UN).

http://www.un.org/esa/socdev/unpfii/documents/DRIPS_en.pdf

UNESCO. 2013. World Summit on the Information Society (WSIS): Towards Knowledge Societies for Peace and Sustainable Development. Paris: United Nations Educational, Scientific and Cultural Organization (UNESCO).

Vizenor, G. 2000. Edward Curtis: Pictorialist and Ethnographic Adventurist. Essay based on presentation at University of California, Berkeley, October 6-7, 2000.

http://www.e-scoala.ro/american/us_cultures/c4d.html

Wapachee, C. 2016. James Bay Students Learn Cree. CBC News, November 3, 2016. Accessed February 15, 2018: http://www.cbc.ca/news/canada/north/james-bay-studentslearn-cree-in-virtual-reality-1.3835500

Citation: Winter, J., \& Boudreau, J. 2018. Supporting Self-Determined Indigenous Innovations: Rethinking the Digital Divide in Canada. Technology Innovation Management Review, 8(2): 38-48.

http://doi.org/10.22215/timreview/1138

Keywords: Indigenous, innovation, digital, technology, makerspaces (cc) BY 


\section{Academic Affiliations and Funding Acknowledgements}

Canadà
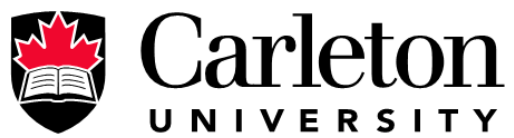

U N I V E R S I T Y

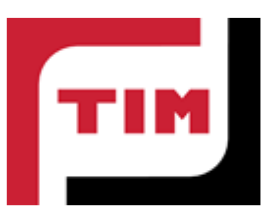

The Federal Economic Development Agency for Southern Ontario (FedDev Ontario; feddevontario.gc.ca) is part of the Innovation, Science and Economic Development portfolio and one of six regional development agencies, each of which helps to address key economic challenges by providing regionallytailored programs, services, knowledge and expertise.

- The TIM Review receives partial funding from FedDev Ontario's Investing in Regional Diversification initiative.

Technology Innovation Management (TIM; timprogram.ca) is an international master's level program at Carleton University in Ottawa, Canada. It leads to a Master of Applied Science (M.A.Sc.) degree, a Master of Engineering (M.Eng.) degree, or a Master of Entrepreneurship (M.Ent.) degree. The objective of this program is to train aspiring entrepreneurs on creating wealth at the early stages of company or opportunity lifecycles.

- The TIM Review is published in association with and receives partial funding from the TIM program. 